\title{
Literary learning
}

\author{
Kaspar H. Spinner* - University of Augsburg, Germany
}

First published in Praxis Deutsch (Spinner, 2006)

Translated from the German by Flora Schiele

\begin{abstract}
Imparting 'literary competence' (understood here as a combination of skills involved in engaging with 'texts' of various kinds, among them film) has always been a core concern within German critical pedagogy. This article presents 11 aspects of literary learning, covering subjective involvement and the development of a text within the imagination; cognitive approaches such as awareness of perspectives, logic of action and linguistic style; and consciousness of genre-related and literary-historical classification. While these suggestions pertain in particular to the teaching of written literature, they are presented here as also having considerable significance for the teaching of film, and with a new introduction from German film education scholar Petra Anders.
\end{abstract}

Keywords: literary comprehension; identification; understanding metaphorical and symbolic language; constructing meaning; film conversations

\section{Introduction}

Petra Anders** - Humboldt University of Berlin, Germany

\section{Spinner's Aspects of Literary Learning (2006) as a reference point for international film education}

In German-speaking countries, the concept of literary learning as explored in the following article by Kaspar $\mathrm{H}$. Spinner is highly influential upon research into literary and media pedagogies (see Leseräume 2, 2015), and thus has a strong relevance for ongoing understandings of film education in Europe and beyond. While Schulze (1996), Abraham (1998), Büker (2002) and others conceptualized learning with literary texts long before Spinner (2006), Spinner's theorization of 11 aspects of literary learning provided an opportunity to summarize some of the central ideas surrounding literary learning, while also reacting to the increasingly standardized view of learning according to the Programme for International Student Assessment (PISA). Such observations apply not only to literacies in print media but also to film. Above all, Spinner emphasizes that aesthetic education must not be replaced by an approach centred around notions of competence, even if such an education cannot then be represented in its entirety by individual operators and levels of competence. The difficulty in defining literary learning in terms of levels arises from the fact that literary learning is more than simply the ability to cognitively understand literary texts. Rather, the handling of texts involves objectives significantly more far-reaching, such as identity formation (in terms of how children find their own desires through texts and media, and learn to understand 
themselves), psychological understanding (in that children get to know, for example, interior views and conflicts), moral judgement (thinking about law and justice, guilt and forgiveness), fantasy and imagination, activation and the expansion of knowledge of the world, as well as aesthetic perception. These abilities are fostered throughout one's life and, of course, remain incomplete.

Utilizing a broad conception of 'text' that encompasses all poetic expression, literary learning is not limited to printed literature. Its concepts can be applied to all kinds of ambiguous texts, such as audio recordings (see Müller, 2012), spoken word (Anders, 2018), theatre plays (see Spinner himself, 2010), computer games (Boelmann, 2015) and, of course, film (Anders and Staiger, 2019).

Although Spinner explicitly cites examples from written literature in the 11 aspects below, these aspects are equally related to the way in which we might approach film from a pedagogical perspective. While this obviously pertains to literary adaptations, literary learning is just as important when dealing with original filmic material. This is fittingly embodied by the notion of 'developing the imagination when reading and listening'. While some may hold the opinion that the viewer does not form any ideas about a film, as the film provides a concrete, visual instantiation of its narrative, others would counter that a film consists of a deliberately selected series of images, combined during the editing process in such a way that the figures shown in individual images, and the organization of locations, production design, colour, sound and music, result in the articulation of sense. When watching a film, the viewer always sees an edited excerpt of a situation that the film can never show in its entirety. Therefore, the viewer must always construct the surrounding context through his or her own experience and knowledge of the world, and through the hints arising from the single picture.

When viewing (and, in this context, this also means reading) a film, we always form ideas, because otherwise we would not understand, for example, the external and internal motives for the behaviour of a character such as Paddington. When adolescents invest their own imaginations into a cinematic character such as Paddington, they learn to use this literary character as a means of testing their own situations (while, in a film such as Paddington (2014), simultaneously learning about cinematic genres such as slapstick comedy). Through experiences of cinema, adolescents develop not only the ability to immerse themselves in films, but also to reflect upon so-called film language (exploring the interaction between subjective involvement and accurate perception): How is colour used within a film and what effect do these colours produce? Which parameters are recognizable, and to what extent does a certain point of view or a character's perspective become clear? Regarding the broader history of film, developing awareness of literary history includes, for example, the citation of and reference to other films within a given film. Adolescents become familiar with literary conversations through film conversations, which in German-speaking countries have shaped Möbius (2008), among others, as Seh-Gespräch [conversation about visual perception]. Thus, the literary conversation is always part of 'talking about art' (Kirschenmann et al., 2011), and the conversation about film therefore is an 'engag[ement] with the inconclusive nature of the process of constructing meaning'.

In conclusion, film is an artistic medium with considerable potential for the sort of literary learning described below by Kaspar H. Spinner, both in and out of school. Spinner's conception of literary learning as a process entailing the formation of identity and perception remains a stimulating basis for international film education with considerable potential for further research, both theoretically and empirically. 


\section{Aspects of literary learning}

\section{Kaspar H. Spinner - University of Augsburg, Germany}

'Literature' and 'learning' are two concepts that are not easily weighed against each other. While one bears connotations of imagination, excitement and enjoyment, the other connotes usefulness, testability and effort. How, then, might the two come together?

The concept of literary learning formulated here is based upon an understanding that there are learning processes that are particular to dealing with literary (fictional or poetic) texts. Literary learning is therefore separate from the concept of reading competence, which - especially since the publication of the first PISA (Programme for International Student Assessment) study - would in comparison seem strongly influenced by pragmatic concerns, and applies to both literary and non-literary texts in the same way, without distinguishing between them. Literary learning has increasingly been the subject of much discussion in the field of German teaching, in connection with efforts to ensure that literature continues to be highly valued in education. Literary learning thus embodies a desire to describe and understand those learning processes that are particular to literature.

Such an approach is supported by the in-depth analysis of PISA data conducted by Cordula Artelt and Matthias Schlagmüller (2004). In addition to examining the overall concept of PISA, Artelt and Schlagmüller (ibid.) analysed the data collected within the study to ascertain whether there were different levels of competence between dealing with texts that were considered literary and those that were not. Finding significant deviations, Artelt and Schlagmüller (ibid.) reached the conclusion that dealing competently with literary texts presents different reading and comprehension challenges to dealing with other texts. Indeed, in contrast to some other countries, young people in Germany seem to perform worse with literary rather than non-literary texts. Within PIRLS (Progress in International Reading Literacy Study), data on reading comprehension of literary and informational texts underwent separate analyses (see Bos et al., 2003: 79-87).

Literary learning and the acquisition of literacy differ not only in regard to the types of text concerned, but also in regard to mediums of transmission. While literacy refers here to the reading of written and printed texts, literary learning also includes auditory and visual forms of reception, such as audiobooks, film or theatre, and thus is actively present in a child's development even before the acquisition of literacy. Before they learn to read, even young children become acquainted with literary texts, from lullabies to audiobooks and visits to the puppet theatre. The oral transmission of literature is also gaining more significance for young people and adults today (see also Praxis Deutsch issue 185/2004 titled Literatur hören und hörbar machen ['Listening to literature and making it possible to listen to literature']).

The concept of competence can serve as a link between literature and learning. Competence has become a key term in recent theorizing about and debates around education. When referring to the teaching of literature, such discussions allow for the specific competences associated with dealing with literary texts to be described, and henceforth encouraged in lessons. In competence-oriented teaching, the focus is not primarily on whether students can reach a suitable interpretation (for example), but rather on whether they are gaining skills that can be used again when dealing with other texts. The goal of literary learning is thus, in this sense, literary competence (see, for example, Abraham, 2005). This includes cumulative learning, and along with it the consideration of whether and how what is transmitted in a teaching session builds 
upon what has already been achieved and prepares for future learning processes. Such goals are not often met by contemporary literature teaching, where the dominant consideration is frequently on how to do justice to the work currently being studied. In this way, teachers taking over a class do indeed ask, if necessary, which texts have been discussed, but are hardly interested in which competences were dealt with in the previous year, although this is exactly what I argue should be built on in competenceoriented teaching. It should also be noted that skills learned in one subject area are not automatically transferred to other subject areas; the transfer must always be expressly stimulated and supported.

Literary learning as the acquisition of reading competence means more than just the promotion of reading, where a motivational emphasis is placed upon passing on the enjoyment of reading. However, an opposition between the promotion of reading and literary learning (as has emerged to some extent in the past in German education) is not to be encouraged (see also Rosebrock, 1999). A more detailed and in-depth understanding of literary styles, if well designed pedagogically, can encourage a positive attitude towards reading literature. It certainly still seems to be the case that the enjoyment of literature is frequently driven out of many students during the course of their education. However, as research into the processes of socialization around reading has shown, there is another set of experiences whereby education can open students' eyes to intense, in-depth literary comprehension. The following, more detailed definition of literary learning that I propose here seeks a pedagogical approach whereby the acquisition of literary competence becomes a tangible asset for students. Literary learning is therefore not reduced simply to the ability to analyse specific literary devices (such as stylistic devices, the study of verse or narrative technique). The view has sometimes been taken, particularly with regard to interpretations of specific works, that one must do justice to literary texts through such analyses of their aesthetic character. This, however, overlooks such central aspects as imaginative engagement or the adoption of other perspectives and viewpoints when reading. As a result, a broader view of what is meant by literary learning has been taken in recent discourse. Pedagogical research has emphatically shown that literary learning is not just the concern of older school children, but is also important from the very beginning of primary school (see, above all, Waldt, 2003), and is prepared for in the processes of socialization surrounding reading that take place before children start school, above all when they are read to (Wieler, 1997).

It should be expressly emphasized that literary learning, as it will be described in this essay, does not cover all the objectives involved in the teaching of literature. For example, literature teaching also serves to explore questions of content (for example, of moral problems), psychological insights, social learning, insight into the history of ideas and the transmission of general knowledge of the world. Literary learning, as the term is used here, does not entail any of these aspects, or, rather, does so only in the sense that a certain way of dealing with such content through literary learning is adopted.

The idea of competence connects the concept of literary learning presented here to more general standards of education, for which the principle of 'cumulative skill acquisition' (as used in the declaration on education standards for the Mittlerer Schulabschluss ${ }^{1}$ made by the Kultusministerkonferenz [Conference of the Ministers

1 The Mittlere Schulabschluss is a German school leaving certificate generally awarded after ten years of schooling. It is awarded to those on a non-academic path and is not sufficient for attending university, but it is more demanding than the Hauptschulabschluss. The Hauptschulabschluss is also a school leaving certificate awarded after nine or ten years of schooling. The different German states have different education systems, so terms for these qualifications can differ. 
of Education and Cultural Affairs] on 4 December 2003 (KMK, 2004)) is equally important. The education standards for the Hauptschulabschluss and for the Mittlerer Schulabschluss draw together explicit objectives for literature teaching under the rubric of 'understanding and using literary texts'. In the standards set for fourth-year students (KMK, 2005), no differentiation is currently made between literary, factual or functional texts, although one can still find individual education standards relating specifically to literary texts. These individual standards can certainly be said to have an effect on all years for which educational standards are set (Years 4, 9 and 10), like a disjointed stringing together of learning objectives. It becomes apparent, however, that the development of coherent models of competence as stipulated by the Kultusministerkonferenz is a task that is yet to be accomplished within the teaching profession in Germany. In the following, more detailed description of literary learning, in some individual aspects I allude loosely to the development of competence over the course of schooling. For the first to sixth school year, there is a similar curriculum of literary learning by Petra Büker (2002: 129-33). Studies on the development of literary comprehension (see the research by Eggert and Garbe 1995: 22-6), carried out largely in the 1980s, also make good reference points, although they would require a wider empirical coverage today.

The 11 aspects of literary learning discussed below range from imaginative involvement in a text to cognitive literary and historical awarenesses, requiring a greater degree of distance. All aspects, however, are still relevant to school children of all ages (primary school children encounter the historicity of literature through antiquated words in fairy tales, for example).

\section{Developing the imagination when reading and listening}

Literary texts encourage the development of the imagination. Otfried Preußler (1998: 58-9) described this as follows:

The reader does not only have to decipher the silent code of the letters and put them together to form words, he also has to turn words and sentences into images - more than this: he must make these images in such a way that they can be perceived with all the senses. He does not only have to see what is being recounted by the author, he also has to hear, smell and taste it, feel for it with his hands and understand it in his heart. ... He is almost in the role of a director who has my text in front of him as a script, and then has to stage my story using just this script.

The imaginative visualization of sensation is a fundamental aspect of (literary-) aesthetic experience. It can be found in Germany's national education standards for Year 4 in the phrase 'develop vivid mental pictures when reading and listening to literary texts'. With regard to literary learning, this should not be simply any mental picture, but rather an 'evolving' (Köppert, 1997) of what is already inherent in the text, and should thus serve a deepened understanding of the text. Such an imagining may concern the description of landscapes and spaces, individual objects, characters, sounds, or the reliving of moods. Creative, productive processes of engaging with texts, when approached methodically, can thus foster the development of the imagination. With regard to the progression of such learning, students develop increasingly different imaginations, and show flexibility in their imaginings (in the course of reading, one repeatedly has to modify one's imagination due to new information in the text) and can also relate different ideas to each other (such as home decor with the personality of a character). Children often tend to assign their own everyday experiences to a text and 
remain stuck in these, even if the text opens up other perspectives (what is referred to by the developmental psychologist Jean Piaget as egocentrism). In contrast, young adults frequently risk failing to make an effort to develop the text, and may dismiss it with a generalized statement, thereby missing its specific vibrancy. (This can sometimes reflect the manner in which literature is taught, when teaching focuses only on the intention of the author or on a generalized understanding.) The challenge is therefore to retain the childish intensity of the way in which texts are imagined and to bring about increasing differentiation, flexibility and text-oriented precision.

\section{Using the interaction between subjective involvement and accurate perception}

Through my discussion of imagination, it should already be clear that a feeling of being personally addressed by a text is just as important for intense literary comprehension as attention to the text itself. Subjective involvement and attentive text perception can enhance each other, and therein lies one of the major goals of literary learning. The tension between subjectivity and textual reference has long been a subject of discussion in the field of literature teaching (in the tradition of hermeneutics as well as in the aesthetics of reception). Pedagogically, this is often framed in such a way as to suggest that we need to move on from a subjectively 'blinkered' initial reception (see Kreft, 1977: 379) to objective analysis. This progression, however, does not do justice to the interplay between subjectivity and text orientation, which is the hallmark of literary comprehension. For example, a children's book with a main character who is suffering from a feeling of inferiority (a major theme in contemporary children's and young adults' literature) can become a surface onto which a child can project their own corresponding feelings and, through such involvement, can bring about intensely fulfilling, accurate reading. This then enables the reader to perceive aspects of the text that they are not initially conscious of having personally experienced, leading to enhanced self-knowledge. Discoveries in a text can also induce self-reflection and this, in turn, can strengthen interest in accurate text perception. Processes of alienation also play an important role in this interplay between subjective involvement and accurate text perception: one sees oneself and one's experiences in a literary text as if in a mirror, and at the same time, one becomes irritated.

The implementation of these different aspects of literary learning in teaching methodologies is made harder by the fact that they cannot be tested: they concern individual processes that are not directly observable and for which students would be justifiably entitled to reserve the right to their own privacy. When reading biographical studies, however, as compiled and analysed in research into the socialization of reading, it can be seen that it is exactly this subjective involvement that causes intense reading experiences that remain a long time in the memory. This can be achieved not just through private reading, but also in literature classes, as positive comments on literature classes repeatedly show (these, like negative comments, exist in biographical studies of reading). The borders of what can be tested cannot therefore be used as an argument to exclude this aspect from teaching.

In primary school, it is still relatively unproblematic to situate this subjective aspect as a central aspect of enquiry. This can be done through the description of similar personal experiences to those in a text. As students get older, the fact that literature enables one to process personal matters through conversations about fiction (or in productive, creative work), without others being aware of the level of subjectivity, becomes increasingly important. (Here, questions from teachers such as 'What was it like for you when you were in love?' are often out of the question.) Teachers usually 
have a good eye for (or, perhaps I should say, a sense of) whether their lesson reaches the student as a person and whether there is an increase in the complexity of individual critical awareness.

\section{Active awareness of linguistic composition}

Another aspect of the text perception discussed in the previous section is the attention to linguistic composition, which is important for the aesthetic effect of literary texts. This extends from the more intuitive perception of sound and rhythm to text analysis, including analysis of language and style. Within such an awareness of linguistic composition, it is important that the purposive function of such aesthetic effects is recognized and experienced. If analysis degenerates into purely formal determinations, say of the rhyme scheme, and becomes disconnected from the experience of sound, one can no longer speak of meaningful literary learning. Even primary school children are open to simple literary forms such as parallelism, juxtaposition, repetition and opposition, which can be found in abundance in many nursery rhymes, picture books and stories for children. For example, reflecting on whether the repetition of words in a text is meaningful, and what effect this provokes in us, teaches a basic level of awareness of linguistic composition. This can be used to introduce the difference between literary language and everyday language. The aim here is that students are able to make increasingly independent observations regarding linguistic composition, and in doing so develop a certain joy of discovery. Experimenting with formal structures themselves - for example, writing their own texts in the style of a literary model - can have a particularly lasting impact, as students experience how particular stylistic devices can produce particular effects. Such productive processes exploring the possibilities of composition extend from inserting missing words to rewriting texts from a different narrative perspective, which then teaches students about narrative technique.

\section{Understanding the perspectives of characters in literature}

In narrative, and sometimes also in dramatic and lyric texts, the perception of characters plays a central role for the reader, listener or viewer. The faculty of imagination mentioned earlier becomes important here: not only does a literary text inform you about characters, it also invites you to imagine them. In turn, reception is about the interplay between subjective involvement and accurate text perception, here in terms of identification and distinction (see Hurrelmann, 2003). An intense relation to literary characters arises when we recognize our own feelings and views, even our desire for other life opportunities, in the text. At the same time, literary comprehension also means thinking within the logic of the text and perceiving the foreignness of characters. The experience of otherness, which is to say irritation due to otherness, can, in turn, lead to increased self-reflection. In the German education standards for reading in Year 4, the adoption of other perspectives is mentioned explicitly: 'when working with literary texts, show sensitivity to and understanding for thoughts and feelings and interpersonal relationships' (KMK, 2004).

The connection between the internal world (characters' feelings, thoughts, experiences and memories) of a narrative and the external plot plays a central role in understanding characters. This is sometimes developed explicitly in texts, but must also often be deduced by the reader from signals in the text. As modern literature in particular focuses more strongly on characters' inner psychological processes, the adoption of perception, from compassion and empathy to cognitive struggle with otherness, is increasingly gaining significance. This is even true of children's and 
young adults' literature, in which a strong element of the psychological has gained prominence in recent years (this even applies to picture books).

In addition to the nuanced perception of individual characters and their inner worlds, the network of relationships between characters within a given narrative plays an important role in literary comprehension. This touches upon what is arguably one of the key themes in literature, developed most strongly in drama: in addition to external interactions, literary texts frequently explore the complications around the ways in which feelings of affection, love, hate, jealousy, inferiority and indifference determine the ways in which different people coexist.

On the basis of previous research, one can establish a course that looks to develop the ability to adopt other literary perspectives, which would then lay the foundations for a proficiency model (although this would admittedly require more indepth empirical studies). On a basic level, children understand literary texts largely through the perspective of an individual character, with whom they are able to identify through their own life experience. A second level is reached when differences between characters (with regard to their personality, emotions and opinions) can be clearly recognized. In simple form, such perceptions remain disconnected from each other. When the different views and attitudes of characters can be related to each other, and the connections to their living environment recognized, a higher level again has been reached. It is even more of a challenge to bring narrative styles and bring the perspective of the narrator into play (such as the irony in Thomas Mann's character depictions). To be able to connect all these aspects with each other would signify a particularly elaborate form of understanding of characters (this account is based on Andringa, 2000: 94-5). In addition to a model based on the interaction of character perspectives, progress in learning can also be seen when students know how to deal with characters' ambivalent (contradictory, unclear, unstable) inner states. This means, for example, that categories such as good/bad, happy/sad, wilful/passive, and so forth are treated with increasing flexibility in interpretations.

\section{Understanding narrative and dramaturgical logic of action}

When considering the significance of networks of relationships between characters in literary texts, the creation of text-internal links is important for competent literary comprehension. Above all, this is connected to the manner in which a literary text primarily does not refer to text-external facts: the literary world must be deduced from the context. Bottom-up processes (from individual to whole), as cognitive psychologists might say, gain a special significance in literary reading. Many aspects of a text can only be understood when related to something that has already been encountered in the text. That which may be viewed as happenstance in everyday perception (such as the colour of a person's dress) gains additional significance within a literary text, because it is integrated into the logic of the text. In contrast to a discursive text, for example, in which logical links are made explicitly, literary texts leave the creation of connections more strongly to the reader. In Effi Briest (1895, translation 1986), Theodor Fontane does not explicitly say what significance Effi's swing has for the contextual meaning of the novel; the reader must deduce this themselves. For readers who can recognize (or better, establish) such connections, texts become more meaningful and multifaceted, and therefore more interesting.

As early as primary school, students should be encouraged to look at the context of a text, from the perspective that much can only be inferred if you connect different points in the text to each other. In the further course of education, increasingly complex 
texts can be used, even those that partially refuse establishment of coherence (such as modern plays) or that are made more difficult through non-linear narration.

\section{Dealing consciously with fictionality}

Dramaturgical and the narrative logic of action are connected to the fictional character of literary texts. Fictionality here denotes the manner in which literary texts do not refer directly to text-external reality, but rather create their own reference system. Children still find it difficult to recognize the difference between fictional texts and direct statements about reality. They are not, however, unfamiliar with fictionality, for they practise it themselves during role-playing games. Fictionality is therefore something that children are already intuitively familiar with.

Fictionality is by no means a simple phenomenon, however, as literature interweaves fiction with references to reality in a great number of ways. Modern literature, especially, arguably operates on the border between the text-internal and the text-external: for example, in In My Brother's Shadow: A Life and Death in the SS, the author Uwe Timm (2005) takes real-life documents as his starting point, but must reconstruct the past in his imagination in his search for truth, and use literary means in order to portray it. The parabolic significance of literary texts, whereby the instruments of fiction are used to convey insights or contemplations about reality, is also included in the area of tension between fiction and reference to reality.

Here, a multifaceted phenomenon already accessible to primary school children is that of animal characters in literary texts. Animal characters are often so humanized that it is clear that they are fictional. There are, however, some novels based on findings from biological research, such as Marion Dane Bauer's (2002) wolf story Runt. While it is a fictional text, Runt (as Bauer outlines in the afterword) attempts to convey something of the real behaviour of wolves, and as such the narrative contains certain aspects of a non-fiction book. As Bauer (ibid.: 134) writes: 'Runt and his pack are, of course, entirely fictional. And yet most of what they do in this story - except for talking - is based on observations made by wolf biologists.' Framed in this manner, the complex interweaving of the text-internal and text-external can also be understood by primary school children. In the course of education, dealing with fictionality can lead to questions critiquing knowledge and, indeed, a constructivist might say that what we believe to be reality is also a fiction. As fiction and reality are not simple opposites, and because it is exactly in this register that many of the possible effects of literature lie, the issue of Praxis Deutsch that is dedicated to this topic bears the title Vom Spiel der Fiktionen mit Realitäten ('On the way fiction plays with realities') (issue 180/2003).

\section{Understanding metaphorical and symbolic language}

Many teachers consider the understanding of metaphorical and symbolic language to be a central objective of teaching literature (the education standards for the Hauptschulabschluss mention 'verbal images', and those for the Mittlerer Schulabschluss additionally mention 'the metaphor' (KMK, 2004)). However, according to recent theoretical discourses, it is now contested whether the use of metaphor is truly a particular characteristic of literature, for metaphors are also now recognized as a widespread phenomenon of non-literary language (think, for example, of 'mouse', 'menu', 'cut and paste' and 'window' in terms of language about computers). Metaphors and symbols in literary language do not work, however, in the same manner as everyday language. When I talk about my computer's mouse, I do not picture an actual mouse. In contrast, the literal meaning remains present in literary texts. In Eichendorff's 
famous poem 'Moonlit night' (1837), when he writes 'then soft my soul unfolded/wings spreading open wide', it would not be adequate to only see the figurative meaning: the point is rather that in this poem the extension of the wings creates an image of flying. In a similar manner, symbolic language cannot simply be reduced to abstract meaning, but must rather be taken seriously on an imagistic level.

In literary texts, metaphors and symbols in general are seen to occupy a pictorial register above sentence level. In this way, the vivid theme of flying in Nicky Singer's Feather Boy (2002) appears in multiple variations and connects the different plot lines on a metaphorical-symbolic level (there is no real flying in this story).

Children are still barely able to explain metaphors and symbols, but this does not mean they do not have an intuitive understanding of them (such as, for example, the forest in fairy tales as a place of danger and a place to prove yourself). Simple access to these symbolic dimensions of meaning can be granted, for instance, through working with personal associations and their connection to literary characters' perspectives, such as 'What connotations do forests have for you?; What does the forest mean for Red Riding Hood or for Hansel and Gretel?'. This approach should help develop an understanding that 'forest' within a literary text has an enriched meaning that has to be deduced from the textual context rather than from personal associations. As a programme of education progresses, the metaphorical and symbolic relationships in a text can be studied with a greater degree of consciousness. Here, as with the logic of action, it is a question of searching for connections within the text. Only these connections can show whether a river has connotations of transience, rootlessness or freedom within the context of a given story. Knowledge of traditional symbolism can help with interpretation, but it is important to check against the text whether a symbolic meaning is plausible in each particular case. For older students, there can be a danger of arbitrary, speculative interpretation of symbols (just as there is the danger of quibbling over-interpretation within the study of literature). Engaging competently with metaphors and symbols therefore comes with a certain amount of caution, and it is completely appropriate here to designate interpretations as 'possible' (along the lines of, 'Can you see a connection ...?'), which leads to the following aspect of literary learning.

\section{Engaging with the inconclusive nature of the process of constructing meaning}

The cautiousness advisable when interpreting literary texts also reflects the way in which literary texts invite processes of constructing meaning that do not readily come to a definitive end (in the same way that a symbol cannot simply be rendered into a firm, abstract meaning). From the perspective of literary science, this understanding is primarily the result of reception aesthetics and deconstructivism. Therefore, school children should also learn to deal with this open-ended nature of literary texts. In my experience, they do not always find this easy, as - largely due to their wider experiences at school - they tend to want to reach firm conclusions. The objective of literature classes cannot, however, be to take all aspects of mystery out a text. Rather, the point is to show a willingness to become entangled in processes of understanding that do not promise any conclusive results and are therefore multifaceted. Such processes will necessarily include not reacting to unfamiliar ways of expression with hasty defence. Only in this manner can literature develop the function as a medium that allows for problematization: that it does not always simply fit into our routine common understanding is what makes literature simultaneously irritating and fascinating. 
Children themselves can be perfectly (and sometimes particularly) open to unfamiliar forms of expression (such as nonsense texts). In this respect, making children aware of the inconclusiveness of meaning construction and ambiguity (aspects that are frequently interconnected) is not therefore an activity that should be reserved for higher years. Progress in literary learning can above all be glimpsed when increasingly complex contexts of meaning and aspects of ambivalence emerge in discussions. A Kafka text, for example, presents different challenges to a children's nonsense story, but also enables extensive reflection and opens up productive and creative avenues.

The deviation of literary learning from the learning generally tested in reading tests becomes particularly apparent when considering this inconclusiveness of meaning. In the case of some questions set during tests, it could even be said that questions that are interesting from a literary point of view start precisely at the point at which the test concludes the effort of interpreting. Take, for example, Brecht's Mr Keuner story 'The helpless boy': if the correct answer to a multiple-choice question 'What is the central aim of the text?' is 'To demand resistance in the face of injustices suffered', then a reasonable but rather banal interpretation has been made (this is an example cited by Köster, 2005: 183). However, if one looks at the text more closely and recognizes that the boy had indeed shouted, but was not heard (he answers the man's question whether or not he could shout louder with a 'no'), the text suddenly becomes more intricate and, with that, more interesting. Literary learning therefore means perceiving and taking seriously aspects of texts that have not yet (as far as I am aware) been addressed in reading competence tests.

\section{Becoming familiar with literary discussion}

I argue that inconclusive interpretations can be best developed in open discussion, which might thus be referred to as literary discussion. The ability to take part in such discussions should be considered an underlying aspect of literary learning competence (not just as a teaching method). Taking part in literary culture includes the ability to interact appropriately with others about your and their experiences of a text (in this context, we talk about 'follow-up communication'). Literary discussion asks of its participants that they contribute their own interpretations; that they understand the suggestions of others; that they understand discussion to be exploratory; and that they help contribute to a balance between giving their own thoughts while also taking seriously those of others, alongside references to the text. In current debates within the profession, much attention has been given to the conception of the literary discussion developed theoretically and tested empirically by the Heidelberg research group surrounding Gerhard Härle. Literary discussion must be practised with students over a significant period of time, although this is not unproblematic with class sizes of 25 to 35 participants. Literary discussion can be found in the German education standards in the phrases 'develop personal thoughts on a text, take a position on a text and talk about texts with others' (Year 4) and 'develop personal interpretations of the text, prove these using the text, and discuss them with others' (Mittlerer Schulabschluss, similar in the Hauptschulabschluss standards (KMK, 2005)).

Following the work of Thomas Zabka (2003), individual ways of expressing interpretations in discussion can be typified in even more detail, namely expressive interpretations (personal impressions and interpretations as subjective announcements), suggestive interpretations (connected to a claim to truth), explanatory interpretations (in which interpretations are explained, giving an additional argumentative character), and discursive interpretations, in which the different possibilities of interpretation are pursued without the urge to eliminate ambiguity. In the latter, conclusions about 
plausibility (see Nordhofen, 2003: 164) play an important role. In this manner, it is possible to define observable features of dialogue that should be taught as competences in dealing with literature.

\section{Understanding genres as prototypes}

An aspect of literary learning that traditionally has been important in literature teaching is acquiring a knowledge of genre: the ability to recognize and name the respective features of fairy tales, short stories, novellas, and so on is considered by many to be an important objective in the teaching of literature. Even so, determining features in this way is not without its problems, as the majority of texts do not conform clearly to such features (see, for example, Grimm's fairy tales). Teaching genre is therefore not always very enlightening for students, and also harbours the risk that the particularities of any given text are no longer taken seriously, as the focus becomes merely upon what is typical of the genre. It must also be said, however, that genre terms are in everyday usage, and it would therefore seem necessary to become familiar with them. My recommendation is that teachers use the approach of prototype theory, whereby students become acquainted with typical examples of fairy tales, fables, and so on, and connect the relevant terms with them, but do so more in terms of a holistic understanding with the aid of an example, rather than on the basis of rote-learned features. The illusion should not be created that all texts can be categorized into genres. Such typified examples provide anchor points for orientation within the literary range and, through comparison, can subsequently refine awareness of deviations from the genre. Such insights and considerations can arguably be developed as early as primary school.

\section{Developing awareness of literary history}

An awareness of literary history also belongs to traditional conceptions of literary education. However, even here, there is controversy within the profession as to what this should mean. The idea of particular eras of literary history has repeatedly come under scrutiny. In competence-oriented teaching, development of the ability to understand a literary text as a reaction to what has preceded it (in terms of its sense of continuation or opposition) can be more important than learning the typical features of literary eras. Here, the priority would seem more to be setting objectives largely for the older school years. It can be useful to include history of art, music and film, and to teach (for example) expressionism as it is distinct from realism or Jugendstil. It is often unclear how innovative a literary work appeared to an author's contemporaries, until one can visualize a horizon of contemporary expectation. This can also make one's own perception of literary works from the past feel more alive.

Insight into intertextual connections also forms part of an awareness of literary history. This can be initiated as early as primary school, as many children's books allude to earlier texts, such as fairy tales.

\section{Literary learning and the aesthetic media}

In the 11 aspects presented above, literary learning has been discussed with regard to texts (transmitted in writing or orally), without explicitly taking audiovisual media into account. This distinction, which conforms to traditional usage, is not without its problems. We currently consider drama performed in theatres as literature, but do not extend the same consideration to film. In these terms, how should we consider 
theatrical performances that are recorded and shown on television? I argue that it is neither pedagogically meaningful nor necessary to draw strict borders. Rather, it would seem appropriate to connect literary learning with media-aesthetic learning. Many of the sub-competences presented here apply to film as well as to literature - for instance, an understanding of the symbolic, consciously dealing with fictionality, or the understanding of dramaturgical logic of action. Even if simply for pragmatic reasons of available time, it makes sense to link literary and media-aesthetic learning together in such a way that there is transfer between them. In doing so, the path does not always have to go from book to film, as is traditionally the case. Conversely, for example, with the help of films, one can develop an interpretation of the externally visible (facial expression, gesture, clothing, ways of speaking, and so on) with respect to the inner world of characters, and then work on a literary text in a similar way (while also taking medium-specific differences into account).

\section{Factual texts and literary learning}

The strict distinction that has been made here between literary texts and factual texts - a differentiation that has been made in the interest of clarity (see also Praxis Deutsch, issue 189/2005 Sachtexte ('Factual texts')) - should also be placed in context. Much of what I have discussed also applies to the teaching of factual texts, particularly in cases where such texts are not integrated into a concrete situational context. Reading a recipe for a planned Sunday lunch, or listening to the weather forecast before a planned walk, obviously has little to do with literary comprehension. This is not the case, however, for reading a factual book (for example, about a different culture) because you find it fascinating to imagine different worlds, or enjoying the coverage of a crime because it is exciting, or reading an autobiography because you are interested in the inner life of another person. Literary learning, when you understand it more closely, relates not only to doing justice to literary texts, but also aims to foster an approach to reading that is typically developed through literary texts, but can also have a function in relation to other texts. It is therefore very one-sided if lessons dealing with factual texts are geared almost exclusively towards the transmission of information and, where relevant, critical reading. It is important, particularly in regard to promoting reading among boys, to make clear that their preference for factual books also satisfies imaginative needs.

\section{Reading, listening and writing}

Literary learning takes place first and foremost in contact with texts via reading and listening, and in the case of theatre or film, also via watching. However, it also plays a role in writing, and not just because productive and creative tasks can be helpful in numerous ways for the development of competences regarding the reception of literature, but also because literary modes of expression play a role within the framework of creative writing. Narrative logic of action or attention to linguistic composition, for example, are also central here. Especially with regard to primary school, the strong connection between reading and writing with regard to literary learning has been clearly proven (see, for example, Dehn, 1999; Kruse 2003).

\section{Methods: Varied, but not arbitrarily}

In my description of the different aspects of literary learning, it should hopefully be clear that diverse approaches to the teaching of literature are possible during lessons. 
Analysis and interpretation in class discussion and in written assignments, open literary discussion, situations where texts are read aloud, creative assignments alongside other approaches are all possible. With regard to literary learning, however, it is important that any given method does not obscure an overall, holistic approach, thus losing its connection to the development of literary experience and competence. This is not always easily achievable: the analysis of rhetorical figures in texts quickly becomes an end in itself, and the pleasure a teacher may take in the industriousness of his or her students during creative work may mean that they do not reflect sufficiently upon which competences are being targeted. I argue that the best approach consists of a considered combination of different methods, such as open discussions, creative work, descriptions of scenes, analytic contemplation, and so on.

\section{Explicit and implicit literary learning}

The role of implicit learning within programmes of literary learning can also be seen clearly through creative writing. For instance, when children write fantasy stories, they generally tend to follow strong narrative patterns that are drawn from literary experience (such as a plot structure that involves complication and resolution, a main character and an antagonist). This is frequently done unconsciously, and children can rarely name such structures. Similar to the manner in which they are able to speak (largely) grammatically correct sentences without having a command of grammatical terminology, children also have implicit knowledge of narratives. In most contemporary teaching, the focus is almost exclusively on explicit knowledge, conscious analysis and interpretation. This is problematic for three reasons. First, competent literary reading is always based on implicit knowledge. It is not always possible to become conscious of everything that is happening in the mind when reading and listening to literary texts. Second, from a perspective of learning psychology, if one does not include implicit learning processes, one wastes considerable learning opportunities. As cognitive approaches to learning psychology have shown, all learning takes place by making links with knowledge that already exists. This can be rendered productive in lessons where relevant implicit knowledge is available. Third, with regard to the comprehension of literature, that which children and young people pick up implicitly is often significantly richer than that which they can explicitly name and explain. This would seem to be demonstrated repeatedly through creative writing in which students follow the pattern of a text to write their own text (without preceding explicit analysis). They use characteristics of the template, but when asked about the parallels between the original text and their own text, they frequently find it difficult to name them. Drawing links between such templates for creative work and follow-up analytic reflections can greatly enhance learning, as this allows conscious explanation to build upon the implicit competences realized when writing.

Being read to by a teacher is also important for implicit literary learning. If such an activity is viewed not simply as a chance to relax or as a reward, but rather within the context of literary learning, then, while reading aloud, teachers can also have in mind some of the sub-aspects of literary learning presented here, and take these aspects into account in their presentation. For example, teachers might read aloud in such a way that listeners are able to create mental pictures (the tempo of reading and pauses play a big role here); they might make demanding literary devices more accessible using intonation - for example, by slightly lowering the voice for free indirect speech; and they might slightly emphasize words that have a central symbolic meaning - for example, by making a short pause before speaking the word. 
If literary learning is viewed and encouraged as both implicit and explicit learning in this sense, motivation to read and literary learning do not have to stand in opposition to each other.

\section{Notes on the contributors}

Kaspar Heinrich Spinner received his doctorate under Emil Staiger (Zurich), worked as an assistant to Bernhard Böschenstein (Geneva) and was Professor of German Studies/ Literature Didactics in Germany until 2006. In 2011, he received an honorary doctorate from the Pädagogische Hochschule Weingarten (Germany). Spinner established productive methods in the didactics of German teaching and achieved a great reception and significance in German didactic discourse with his Aspects of Literary Learning (2006).

Petra Anders studied German literature, history and philosophy at the University of Göttingen, Germany. She received her doctorate for a study on poetry slam, became junior professor for media didactics at the University of Leipzig, and from 2016 to 2018 was Professor of German Didactics at the Free University of Berlin. Since 2018, she has been Professor of German Didactics for Primary Schools at Humboldt University of Berlin. Her research focuses on film didactics and new media literacies.

\section{References}

Abraham, U. (1998) Übergänge: Literatur, Sozialisation und literarisches Lernen. Wiesbaden: Westdeutscher Verlag.

Abraham, U. (2005) 'Lesekompetenz, literarische Kompetenz, poetische Kompetenz'. In Rösch, H. (ed.) Kompetenzen im Deutschunterricht. Frankfurt am Main: Peter Lang, 13-26.

Anders, P. (2018) Lyrische Texte im Deutschunterricht. Grundlagen, Methoden, multimediale Praxisvorschläge. 2nd ed. Seelze: Klett/Kallmeyer.

Anders, P. and Staiger, M., with Albrecht, C., Rüsel, M. and Vorst, C. (2019) Einführung in die Filmdidaktik. Stuttgart: Metzler.

Andringa, E. (2000) '"The dialogic imagination": Literarische Komplexität und Lesekompetenz'. In Witte, H., Garbe, C., Holle, K., Stückrath, J. and Willenberg, H. (eds) Deutschunterricht zwischen Kompetenzerwerb und Persönlichkeitsbildung. Baltmannsweiler: Schneider Verlag Hohengehren, 85-97.

Artelt, C. and Schlagmüller, M. (2004) 'Der Umgang mit literarischen Texten als Teilkompetenz im Lesen? Dimensionsanalysen und Ländervergleiche'. In Schiefele, U., Artelt, C., Schneider, W. and Stanat, P. (eds) Struktur, Entwicklung und Förderung von Lesekompetenz: Vertiefende Analysen im Rahmen von PISA 2000. Wiesbaden: VS Verlag für Sozialwissenschaften, 169-96.

Bauer, M.D. (2002) Runt. New York: Clarion Books.

Boelmann, J.M. (2015) Literarisches Verstehen mit narrativen Computerspielen: Eine empirische Studie zu den Potenzialen der Vermittlung von literarischer Bildung und literarischer Kompetenz mit einem schüleraffinen Medium. München: Kopaed.

Bos, W., Lankes, E.-M., Prenzel, M., Schwippert, K., Walther, G. and Valtin, R. (eds) (2003) Erste Ergebnisse aus IGLU: Schülerleistungen am Ende der vierten Jahrgangsstufe im internationalen Vergleich. Münster: Waxmann.

Büker, P. (2002) 'Literarisches Lernen in der Primar- und Orientierungsstufe'. In Bogdal, K.-M. and Korte, H. (eds) Grundzüge der Literaturdidaktik. München: Deutscher Taschenbuch Verlag, 120-33.

Dehn, M. (1999) Texte und Kontexte: Schreiben als kulturelle Tätigkeit in der Grundschule. Berlin: Volk und Wissen.

Eggert, H. and Garbe, C. (1995) Literarische Sozialisation. Stuttgart: Metzler.

Fontane, T. (1986) Effie Briest. Trans. Radcliffe, S. London: Grant \& Cutler.

Hurrelmann, B. (2003) 'Literarische Figuren: Wirklichkeit und Konstruktivität'. Praxis Deutsch, 177, 4-12.

Kirschenmann, J., Richter, C., Spinner, K.H. (2011) Reden über Kunst. Fachdidaktisches Symposium in Literatur, Kunst und Musik. München: Kopaed. 
KMK (2004) Sekretariat der Ständigen Konferenz der Kultusminister der Länder in der Bundesrepublik Deutschland (Hrsg.): Bildungsstandards im Fach Deutsch für den Mittleren Schulabschluss. Online. https://tinyurl.com/y4t5c379 (accessed 31 August 2019).

KMK (2005) Sekretariat der Ständigen Konferenz der Kultusminister der Länder in der Bundesrepublik Deutschland (Hrsg.): Bildungsstandards im Fach Deutsch für den Primarbereich. Online. https://tinyurl.com/y2slc9bz (accessed 31 August 2019).

Köppert, C. (1997) Entfalten und Entdecken: Zur Verbindung von Imagination und Explikation im Literaturunterricht. München: Vögel.

Köster, J. (2005) 'Evaluation von Kompetenzen im Deutschunterricht - neues Etikett oder bildungspolitische Wende?'. In Rösch, H. (ed.) Kompetenzen im Deutschunterricht. Frankfurt am Main: Peter Lang, 175-93.

Kreft, J. (1977) Grundprobleme der Literaturdidaktik: Eine Fachdidaktik im Konzept sozialer und individueller Entwicklung und Geschichte. Heidelberg: Quelle und Meyer.

Kruse, N. (2003) 'Literarisches Lernen in der Grundschule: Textschreiben als Herausforderung literarischen Lernens bei Kindern'. In Brinkmann, E., Kruse, N. and Osburg, C. (eds) Kinder schreiben und lesen: Beobachten - Verstehen - Lehren. Freiburg im Breisgau: Fillibach, 233-354.

Möbius, T. (2008) 'Das "literarische Sehgespräch" als sprachlich-kommunikative Vermittlungsweise bilddominierter Medienangebote'. In Rath, M., Kepser, M. and Frederking, V. (eds) Log In! Kreativer Deutschunterricht und Neue Medien. Festschrift für Hartmut Jonas. München: Kopaed, 141-56.

Müller, K. (2012) Hörtexte im Deutschunterricht: Poetische Texte hören und sprechen. Seelze: Klett/ Kallmeyer.

Nordhofen, S. (2003) Literatur und symbolische Form: Der Beitrag der Cassirer-Tradition zur ästhetischen Erziehung und Literaturdidaktik. Hannover: Siebert.

Preußler, O. (1998) 'Phantasie und Wirklichkeit'. In Pleticha, H. (ed.) Sagen Sie mal, Herr Preußler... Festschrift für Otfried Preußler zum 75. Geburtstag. Stuttgart: Thienemann, 56-65.

Rosebrock, C. (1999) 'Zum Verhältnis von Lesesozialisation und literarischem Lernen'. Didaktik Deutsch, 6, 57-68.

Schulze, T. (1996) 'Erzählen - Geschichten - Lerngeschichten: Anmerkungen zum narrativen Lernen'. In Hohmann, J.S. and Rubinich, J. (eds) Wovon der Schüler träumt: Leseförderung im Spannungsfeld von Literaturvermittlung und Medienpädagogik. Frankfurt: Peter Lang, 261-81.

Singer, N. (2002) Feather Boy. London: HarperCollins.

Spinner, K.H. (2006) 'Literarisches Lernen'. Praxis Deutsch, 200, 6-16.

Spinner, K.H. (2010) 'Literarisches Lernen durch die Beschäftigung mit Theateraufführungen', Karlsruher pädagogische beiträge, 75, S.17-28.

Timm, U. (2005) In My Brother's Shadow: A Life and Death in the SS. Trans. Bell, A. London: Bloomsbury.

Waldt, K. (2003) Literarisches Lernen in der Grundschule: Herausforderung durch ästhetischanspruchsvolle Literatur. Baltmannsweiler: Schneider Verlag Hohengehren.

Wieler, P. (1997) Vorlesen in der Familie: Fallstudien zur literarisch-kulturellen Sozialisation von Vierjährigen. Weinheim: Juventa.

Zabka, T. (2003) 'Interpretationskompetenz als Ziel der ästhetischen Bildung'. Didaktik Deutsch, $15,18-32$. 